JFFI. 2019; 6(1) 340-346

www.jurnal.farmasi.umi.ac.id/index.php/fitofarmakaindonesia

\title{
ISOLASI SENYAWA ANTIOKSIDAN EKSTRAK METANOL KULIT BUAH NAGA MERAH (Hylocereus polyrhizus)
}

\author{
Dwi Indah Pratiwi, Rezki Amriati Syarif, Risda Waris, Faradiba* \\ Program Studi Sarjana Farmasi, Fakultas Farmasi, Universitas Muslim Indonesia, Makassar \\ faradiba.faradiba@umi.ac.id
}

Submission Date: 25-01-2019; $\quad$ Review Completed: 05-02-2019; $\quad$ Accepted Date:10-02-2019

\begin{abstract}
ABSTRAK
Senyawa antioksidan alami dapat ditemukan dalam buah-buahan. Salah satu contoh tanaman yang merupakan sumber antioksidan alami yaitu tanaman buah naga (Dragon fruit). Kulit buah naga (Hylocereus polyrhizus) merupakan limbah hasil pertanian yang selama ini belum dimanfaatkan. Penelitian ini bertujuan untuk mengisolasi senyawa antioksidan yang terdapat dalam ekstrak metanol kulit buah naga merah yang aktif sebagai antioksidan. Ekstrak kulit buah naga merah diperoleh melalui simplisia kulit segar buah naga merah dengan pelarut metanol. Ekstrak metanol yang diperoleh di partisi dengan metode cair-cair menggunakan pelarut n-heksan, etil asetat, dan air. Hasil partisi yaitu fraksi n-heksan kemudian dilakukan rekristalisasi selanjutnya dilakukan isolasi menggunakan kromatografi lapis tipis (KLTP). Berdasarkan hasil KLTP fraksi n-heksan diperoleh 8 pita tetapi hanya pita 6 (isolat I) dan 8 (isolat II) yang aktif sebagai antioksidan setelah penyemprotan DPPH. Hasil spektroskopi UVVis isolat II diduga merupakan senyawa flavonoid. Uji aktivitas antioksidan diketahui bahwa ekstrak metanol, fraksi n-heksan, fraksi etil asetat dari kulit buah naga merah (Hylocereus polyrhizus) memiliki potensi aktivitas antioksidan yang kurang aktif, sedangkan fraksi air tidak aktif sebagai antioksidan.
\end{abstract}

Keywords: Antioksidan, isolasi, kulit buah, buah naga merah (Hylocereus polyrhizus), DPPH

\section{PENDAHULUAN}

Salah satu pemicu utama penyakit degeneratif adalah radikal bebas. Tubuh kita membutuhkan suatu senyawa yang dapat membantu menangkal radikal bebas atau sering disebut antioksidan. Antioksidan adalah senyawa kimia yang dapat menyumbangkan satu atau lebih elektron kepada radikal bebas, sehingga reaksi radikal bebas tersebut dapat terhambat dan mecegah terbentuknya radikal bebas baru (Winarsih, 2007).

Berdasarkan sumbernya, antioksidan dapat dibedakan menjadi antioksidan sintetik dan alami. Seiring dengan semakin meningkatnya kekhawatiran masyarakat terhadap efek samping antioksidan sintetik seperti Butil Hidroksi Anisol (BHA) dan Butil Hidroksil Toluen (BHT) yang bersifat karsinogen, mengakibatkan terjadinya kecenderungan peningkatan penggunaan antioksidan alami (Hermani dan Rahardja, 2005).

Senyawa antioksidan alami dapat ditemukan dalam buah-buahan. Salah satu contoh tanaman yang merupakan sumber antioksidan alami yaitu tanaman buah naga (Dragon fruit). (Cahyono, 2009). Tingkat pemanfaatan dan konsumsi buah naga semakin meningkat, namun umumnya masih sebatas pada pengolahan daging buahnya saja, padahal masih banyak potensi besar yang dimiliki bagian lainnya, salah satunya adalah kulit buah (Budilaksono, 2014). Kuit buah naga merupakan limbah hasil pertanian yang selama ini belum dimanfaatkan. Kulit buah naga mengandung vitamin $\mathrm{C}$, vitamin $\mathrm{E}$, vitamin $\mathrm{A}$, alkaloid, terpenoid, flavonoid, tiamin, niasin, piridoksin, kobalamin, fenolik, karoten, dan fitoalbumin (Jaafar et al., 2009). Menurut penelitian Wu et al., (2006) keunggulan dari kulit buah naga yaitu kaya polifenol dan merupakan sumber antioksidan.

Aktivitas antioksidan ekstrak kulit buah naga juga telah diuji dengan beberapa pelarut yang berbeda tingkat kepolarannya. Penelitian yang dilakukan Mitasari (2012) menyatakan bahwa ekstrak kloroform kulit buah naga merah memiliki aktivitas antioksidan dengan nilai $\mathrm{IC}_{50}$ sebesar 43,836 $\mu \mathrm{g} / \mathrm{mL}$. Kemudian penelitian yang dilakukan Putra (2012) menyatakan bahwa ekstrak n-heksana kulit buah naga merah memiliki aktivitas antioksidan dengan nilai $\mathrm{IC}_{50}$ sebesar $853,543 \mu \mathrm{g} / \mathrm{mL}$. Dengan adanya potensi yang dimiliki oleh kulit buah naga (Hylocereus polyrhizus) memberikan peluang untuk diuji lebih lanjut.

Berdasarkan data diatas, maka dilakukan penelitian mengenai isolasi senyawa antioksidan ekstrak metanol kulit buah naga merah (Hylocereus 
polyrhizus) yang diperoleh dari kota Soppeng, Sulawesi Selatan.

\section{METODE PENELITIAN A.Alat dan Bahan}

Alat-alat yang digunakan adalah alat-alat gelas (Pyrex), alat kromatografi kolom, botol penyemprot penampak bercak, cawan porselin, chamber (Camag), corong pisah, eksikator, lampu $\mathrm{UV}_{254} \mathrm{~nm}$ dan lampu $\mathrm{UV}_{366} \mathrm{~nm}$ (Philips), neraca analitik (Sartorius), pipa kapiler, sentrifuge (Centurion), spektrofotometer UV-Vis (Shimatzu), vacuum rotary evaporator.

Bahan yang digunakan dalam penelitian ini adalah aluminium foil, aseton, aquadest, dichloromethane, DPPH, etil asetat, kuersetin, kulit buah naga merah (Hylocereus polyrhizus), metanol, n-heksan, lempeng KLT, lempeng KLTP, dan silika gel.

\section{B. Pengambilan dan Pengolahan Sampel}

Pengambilan sampel penelitian kulit dari tanaman buah naga merah (Hylocereus polyrhizus) yang diperoleh dari Kabupaten Soppeng, Sulawesi Selatan. Pengolahan bahan penelitian berupa kulit dari buah naga merah (Hylocereus polyrhizus). Selanjutnya sampel dibersihkan menggunakan air mengalir, setelah itu sampel dikupas untuk memisahkan daging buah dengan kulitnya. Kulit buah naga dipotong kecil-kecil.

\section{Pembuatan Ekstrak Sampel}

Sebanyak 7,7 kg sampel kulit buah naga segar diekstraksi dengan cara maserasi menggunakan pelarut metanol. Kulit buah naga merah dimasukkan kedalam wadah maserasi dan diekstraksi dengan metanol hingga sampel terendam sempurna, lalu disimpan selama 1x24 jam dalam wadah tertutup dan terlindungi dari cahaya matahari langsung, sampel diaduk pada jam keenam setelah penyimpanan. Sampel disaring menggunakan kertas saring sehingga diperoleh filtrat. Residu dimaserasi kembali dengan cairan penyari metanol yang baru. Dilakukan remaserasi sebanyak 2 kali. Filtrat yang diperoleh, dikumpulkan dan diuapkan dengan rotary evaporator hingga didapatkan ekstrak kental.

\section{Partisi Sampel}

Sebanyak 70 gram ekstrak metanol kulit buah naga merah dilarutkan dalam aquasest sebanyak $150 \mathrm{~mL}$. Selanjutnya dimasukkan ke dalam corong pisah lalu ditambahkan $200 \mathrm{~mL}$ n-heksana, dikocok secara perlahan-lahan selama 5 menit, setelah itu didiamkan hingga terjadi pemisahan antara ektrak nheksana dan air. Ekstrak n-heksana dipisahkan dengan lapisan air, kemudian ekstrak air dipartisi kembali dengan n-heksana hingga 6 kali sampai larutan berwarna bening. Selanjutnya ekstrak air di partisi kembali menggunakan etil asetat dengan proses yang sama dengan n-heksana. Ekstrak nheksana cair, ekstrak etil asetat cair dan ekstrak air diupkan sehingga diperoleh ekstrak kental.

\section{E. Uji Kualitatif}

Fraksi n-heksan, fraksi air dan fraksi etil asetat kulit buah naga merah (Hylocereus polyrhizus) ditotolkan pada lempeng KLT gel $60 \mathrm{~F}_{254}$ yang berukuran 7 x $1 \mathrm{~cm}$ dengan menggunakan pipa kapiler, kemudian dimasukan kedalam chamber yag berisi eluen n-heksan : etil asetat dengan perbandingan 85:15 sebanyak $5 \mathrm{~mL}$. Selanjutnya profil kromatogram diamati pada sinar tampak, UV $254 \mathrm{~nm}$ dan UV $366 \mathrm{~nm}$. Setelah itu disemprot dengan DPPH (Budilaksono, Wahdaningsih, \& Fahrurroji 2014, h. 4).

\section{F. Fraksinasi dengan Kromatografi Kolom}

Kolom kromatografi dibersihkan dengan metanol kemudian bagian bawah kolom disumbat dengan kapas agar silika gel tidak mencemari tampungan fraksi. Sebanyak $100 \mathrm{~g}$ adsorben silika gel G 60 (0,2-0,5 mm), kemudian dimasukan kedalam kolom dan dimampatkan dengan menggunakan perbandingan eluen pertama.

Fraksi n-heksan kulit buah naga merah (Hylocereus polyrhizus) ditimbang sebanyak $1 \mathrm{~g}$. Kemudian diletakkan diatas permukaan adsorben yang sebelumnya telah dimasukkan dalam kolom, dibawah ekstrak tersebut diletakkan kertas saring. Kemudian fase gerak menggunakan eluen yang berbeda yaitu dichloromethane : metanol dengan perbandingan 100:0 dalam $100 \mathrm{~mL}, 95: 5$ dalam 200 $\mathrm{mL}$, 90:10 dalam $200 \mathrm{~mL}$ dan 85:15 dalam $300 \mathrm{~mL}$.

\section{G. Pemurnian Senyawa secara Rekristalisasi}

Fraksi n-heksan yang membentuk Kristal dilakukan rekristalisasi dengan cara fraksi n-heksan dilarutkan menggunakan campuran pelarut n-heksan dan metanol kemudian di panaskan. Selanjutnya dimasukkan ke dalam lemari pendingin hingga terbentuk kristal.

\section{H. Pemurnian Menggunakan Kromatografi Lapis Tipis Preparatif (KLTP)}

Fraksi n-heksan yang diperoleh selanjutnya dipreparatif. Eluen yang digunakan n-heksan : etil asetat (85:15). Pita hasil KLT-P dikerok dan dilarutkan dalam pelarut metanol, kemudian di sentrifuge untuk mengendapkan silikanya sehingga diperoleh supernatant lalu dikeringkan (isolat). 


\section{Pemastian Kemurnian Isolat dengan KLT 2 Dimensi}

Isolat aktif yang diperoleh ditotol pada lempeng KLT dengan ukuran 5 x $5 \mathrm{~cm}$, kemudian dielusi dengan menggunakan fase gerak $n$-heksan : etil asetat (85:15) untuk arah pertama dan n-heksan : etil asetat (85:15) untuk arah kedua.

\section{J. Identifikasi Isolat dengan Spektrofotometer UV-Vis}

Isolat yang diperoleh diidentifikasi dengan spektroskopi UV-Visible. Senyawa dilarutkan dalam metanol p.a kemudian cuplikan ditempatkan antara monokromator dan detektor. Spektrum yang dihasilkan direkam pada alat pencatat.

\section{K. Uji Aktivitas Antioksidan Menggunakan Spektrofotometer UV-Vis}

Uji aktivitas antioksidan pada ekstrak metanol dan masing-masing fraksi kulit buah naga merah (Hylocereus polyrhizus) berdasarkan pada prosedur Brand-Williams, et al (1997) dan Ahmad, et al (2012) dengan beberapa modifikasi. Pengujian dilakukan dengan memipet $0,5 \mathrm{~mL}$ larutan sampel dari berbagai konsentrasi. Kemudian masing-masing ditambahkan 3,5 mL DPPH. Divortex dan diinkubasi selama 1 jam pada ruangan gelap. Diukur absorbansinya pada panjang gelombang maksimum.

Data hasil pengukuran absorbansi dianalisa presentase aktivitas antioksidannya menggunakan perhitungan nilai $\mathrm{IC}_{50}$.

Persentase inhibisi radikal DPPH dihitung dengan rumus:

$$
\text { Persen Inhibisi }=\frac{\mathrm{A}-\mathrm{B}}{\mathrm{A}} \times 100 \%
$$

Dimana A adalah serapan blangko dan B adalah serapan sampel. Nilai $\mathbf{C C}_{50}$ dihitung dengan menggunakan persamaan regresi persentase inhibisi (Ahmad et al, 2012).

\section{HASIL DAN PEMBAHASAN}

Pada penelitian ini digunakan kulit buah naga merah (Hylocereus polyrhizus) yang diambil pada bulan september 2018 di kabupaten soppeng, provinsi sulawesi selatan. Buah naga merah yang digunakan dalam penelitian ini sebanyak $30 \mathrm{~kg}$. Dari jumlah tersebut diperoleh bobot kulit buah naga merah sebanyak $7.700 \mathrm{gr}$ atau sebesar 25,66\% dari bobot buah keseluruhan.
Tabel 1. Hasil rendamen ekstrak metanol kulit buah naga merah (Hylocereus polyrhizus)

\begin{tabular}{cccc}
\hline $\begin{array}{c}\text { Berat } \\
\text { simplisia } \\
(\mathbf{g})\end{array}$ & $\begin{array}{c}\text { Jumlah } \\
\text { pelarut } \\
\text { metanol } \\
(\mathbf{m L})\end{array}$ & $\begin{array}{c}\text { Berat } \\
\text { ekstrak } \\
(\mathbf{g})\end{array}$ & $\begin{array}{c}\text { Rendemen } \\
\text { ekstrak } \\
(\boldsymbol{\%})\end{array}$ \\
\hline 7.700 & 20.000 & 152,498 & 0,019 \\
\hline
\end{tabular}

Untuk mendapatkan senyawa kimia yang diinginkan digunakan metode ekstraksi yang merupakan metode penyarian zat berkhasiat atau zat aktif dari bagian tanaman dengan menggunakan pelarut yang sesuai (Yuliani \& Satuhu, 2012). Salah satu metode ekstraksi adalah maserasi, metode maserasi dipilih karena prosesnya mudah dan tidak menggunakan suhu tinggi yang memungkinkan dapat merusak senyawa-senyawa kimia yang memiliki aktivitas antioksidan yang terdapat dalam sampel (Pratiwi et al., 2013). Proses ekstraksi yang dilakukan menggunakan pelarut metanol. Dimana pelarut ini dipilih karena memilki kemampuan untuk menarik senyawa polar dan beberapa senyawa nonpolar. Penguapan ekstrak diperoleh ekstrak metanol sebanyak 152,498 gram dari berat simplisia 7.700 gram dengan persentase rendamen $0,019 \%$. Persentase rendamen menunjukkan seberapa besar jumlah kandungan yang dapat terekstraksi oleh pelarut dalam persen (\%).

Ekstrak metanol kulit buah naga merah (Hylocereus polyrhizus) yang diperoleh setelah itu dilakukan partisi, dimana jenis partisi yang digunakan yaitu metode partisi cair-cair dikarenakan ekstrak metanol kulit buah naga merah (Hylocereus polyrhizus) larut dalam air.

Tabel 2. Hasil fraksi n-heksan dan etil asetat kulit buah naga merah (Hylocereus polyrhizus)

\begin{tabular}{cccc}
\hline $\begin{array}{c}\text { Jumlah } \\
\text { ekstrak } \\
\text { kental } \\
(\mathbf{g})\end{array}$ & $\begin{array}{c}\text { Jenis } \\
\text { pelarut }\end{array}$ & $\begin{array}{c}\text { Jumlah } \\
\text { pelarut } \\
(\mathbf{m L})\end{array}$ & $\begin{array}{c}\text { Berat } \\
\text { fraksi } \\
(\mathbf{g})\end{array}$ \\
\hline \multirow{2}{*}{70} & Air & 150 & 57,2793 \\
& n-heksan & 1.200 & 3,3420 \\
& Etil asetat & 1.500 & 3,7997 \\
\hline
\end{tabular}

Fraksinasi pada ekstrak metanol bertujuan untuk memisahkan senyawa berdasarkan kelarutannya terhadap pelarut dengan tingkat kepolaran yang berbeda. Prinsip pemisahan pada proses fraksinasi adalah didasarkan pada perbedaan tingkat kepolaran dan perbedaan bobot jenis antara dua fraksi, yakni fraksi yang memiliki bobot jenis lebih besar akan berada pada fase bawah, sedangkan fraksi yang memiliki bobot jenis yang lebih kecil berada pada fase bawah. 
Hasil dari partisi selanjutnya diidentifikasi senyawa pada fraksi air, fraksi n-heksan, dan fraksi etil asetat kulit buah naga merah (Hylocereus polyrhizus) yang diperoleh dilakukan dengan metode KLT. Tujuannya adalah untuk mengetahui pemisahan senyawa. Metode KLT dipilih karena beberapa kelebihan yang dimiliki, seperti keserbagunaan, kecepatan, dan kepekaannya (Harborne, 1987). Eluen yang digunakan yaitu nheksan : etil asetat dengan perbandingan 99:1, 95:5 85:15 dan 7:3 adapun diambilnya perbandingan tersebut karena telah dilakukan uji kualitatif yang mana terjadi pemisahan noda yang baik pada tingkat kepolaran yang digunakan. Setelah itu dilakukan uji kualitatif antioksidan dengan menyemprot larutan DPPH. Senyawa yang mempunyai aktivitas antioksidan akan bereaksi dengan DPPH yang berwarna ungu dan berubah menjadi senyawa yang lebih stabil menjadi warna kuning (Sarker, et al, 2006). Prinsip DPPH berdasarkan reaksi antara antioksidan dengan DPPH radikal melalui donasi proton. Dengan demikian antioksidan yang bekerja dengan menangkap radikal (radical scavenger) dapat dideteksi dengan metode ini. Prinsip penentuan aktivitas antioksidan metode ini berdasarkan perubahan warna menjadi kuning dari hasil reaksi antara DPPH dengan senyawa antioksidan, sehingga DPPH akan berubah menjadi diphenilpycrilhydrazine yang bersifat non-radikal yang tidak berbahaya. Meningkatnya jumlah diphenilpycrilhydrazine akan ditandai dengan perubahan warna ungu pada bercak menjadi warna kuning (Sarker, et al., 2006).

Tabel 3. Hasil Uji Kualitatif Aktivitas Antioksidan

\begin{tabular}{|c|c|c|c|}
\hline Ekstrak & $\begin{array}{c}\text { Uji } \\
\text { Kualitatif } \\
\text { DPPH } \\
\end{array}$ & $\begin{array}{c}\text { Hasil } \\
\text { Pengamatan }\end{array}$ & Pustaka \\
\hline $\begin{array}{l}\text { Fraksi } \\
\text { air }\end{array}$ & Ungu & - & \multirow{3}{*}{$\begin{array}{c}\text { Perubahan } \\
\text { warna dari } \\
\text { ungu ke } \\
\text { kuning } \\
\text { (Molyneux, } \\
\text { 2004) }\end{array}$} \\
\hline $\begin{array}{l}\text { Fraksi n- } \\
\text { heksan }\end{array}$ & Kuning & + & \\
\hline $\begin{array}{c}\text { Fraksi } \\
\text { etil } \\
\text { asetat }\end{array}$ & Kuning & + & \\
\hline
\end{tabular}

Pada hasil partisi yaitu fraksi n-heksan teridentifikasi adanya kristal. Kemudian kristal tersebut dilakukan rekristalisasi untuk melakukan pemurnian dengan pelarut n-heksan dan metanol. Dari hasil rekristalisasi yang diperoleh dilanjutkan dengan proses isolasi menggunakan kromatografi lapis tipis preparatif. Proses isolasi kromatografi lapis tipis preparatif terjadi berdasarkan perbedaan daya serap dan daya partisi serta kelarutan dari komponenkomponen kimia yang akan bergerak mengikuti kepolaran eluen, oleh karena daya serap adsorben terhadap komponen kimia tidak sama, maka komponen bergerak dengan kecepatan yang berbeda sehingga hal inilah yang menyebabkan pemisahan (Munson, 2010). Proses elusi kromatografi lapis tipis preparatif eluen yang digunakan yaitu n-heksan : etil asetat (85:15) dalam $100 \mathrm{~mL}$.

Tabel 4. Hasil KLTP dari fraksi n-heksan kulit buah naga merah (Hylocereus polyrhizus) yang disemprot dengan DPPH

\begin{tabular}{cccc}
\hline Pita ke & $\begin{array}{c}\text { Penyem } \\
\text { protan } \\
\text { DPPH }\end{array}$ & $\begin{array}{c}\text { Hasil } \\
\text { pengamatan }\end{array}$ & Pustaka \\
\hline 1 & Ungu & - & \\
2 & Ungu & - & Perubahan \\
3 & Ungu & - & warna dari \\
4 & Ungu & - & ungu ke \\
5 & Ungu & - & kuning \\
6 & Kuning & + & Molyneux, \\
7 & Ungu & - & \\
8 & Kuning & + & \\
\hline
\end{tabular}

Pada kromatografi lapis tipis preparatif adsorpsi dan partisi berdasarkan pada jumlah dan cara penotolan cuplikan yang berkesinambungan yang memberikan hasil elusi berupa pita. Berdasarkan hasil KLTP didapatkan hasil dari pita 6 dan 8 yang menunjukkan aktivitas antioksidan dengan penyemprotan DPPH. Pita-pita yang dihasilkan kemudian dikerok dan dilarutkan dalam pelarut metanol. Kemudian disentrifuge untuk memisahkan silika gel dan supernatant yang didapatkan sehingga diperoleh isolat.

Tabel 5. Hasil kristal isolat kulit buah naga merah (Hylocereus polyrhizus)

\begin{tabular}{ccc}
\hline No. & Isolat & Berat (g) \\
\hline 1 & I & 0,1398 \\
2 & II & 0,0373 \\
\hline Isolat & yang & diperoleh selanjutnya diuji
\end{tabular}
kemurniannya dengan metode KLT dua dimensi. Pada uji KLT-dua dimensi menggunakan eluen nheksan : etil asetat (85:15) untuk arah pertama dan arah kedua. Hasil elusi nampak pada UV $366 \mathrm{~nm}$ dan diperoleh satu bercak tunggal. 


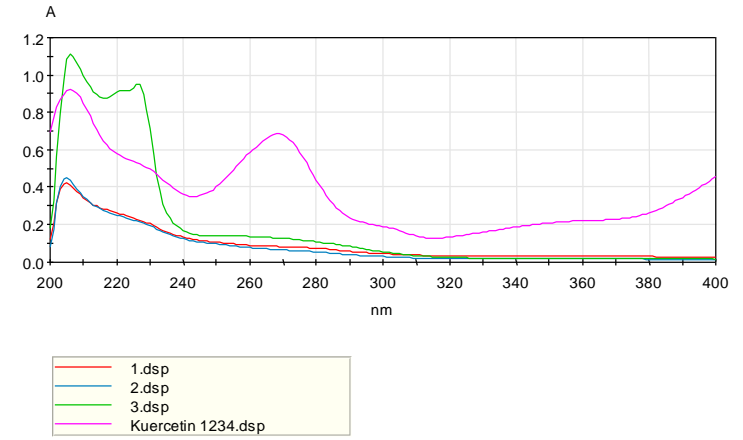

Gambar 1. Data hasil spektrum isolat fraksi nheksan kulit buah naga merah (Hylocereus polyrhizus)

Selanjutnya dilakukan pengujian dengan alat spektrofotometri UV-Vis untuk mengetahui puncak serapan yang dimiliki oleh isolat kulit buah naga merah (Hylocereus polyrhizus), yang didapatkan hasil puncak serapan ada dua puncak yang menandakan fraksi n-heksan kulit buah naga merah (Hylocereus polyrhizus) adalah golongan senyawa flavonoid.

Pada penelitian ini juga dilakukan uji kuantitatif aktivitas antioksidan dilakukan dengan menggunakan peredaman radikal DPPH $(1,1$ Diphenyl-2-picrylhidrazyl). Metode ini dipilih karena Metode DPPH merupakan metode yang sederhana, cepat, dan mudah untuk skrening aktivitas penangkap radikal beberapa senyawa (Koleva et al., 2001), selain itu metode ini terbukti akurat, reliabel dan praktis. Metode DPPH memberikan informasi reaktivitas senyawa yang diuji dengan suatu radikal stabil. DPPH memberikan serapan kuat pada panjang gelombang $517 \mathrm{~nm}$ dengan warna violet gelap. Penangkap radikal bebas menyebabkan elektron menjadi berpasangan yang kemudian menyebabkan penghilangan warna yang sebanding dengan jumlah elektron yang diambil (Sunarni, 2005).

Tabel 6. Pengukuran absorbansi, persen inhibisi, dan nilai $\mathrm{IC}_{50}$ dari ekstrak metanol, fraksi n-heksan, fraksi etil asetat, dan fraksi air kulit buah naga (Hylocereus polyrhizus)

\begin{tabular}{cccccc}
\hline Sampel & $\begin{array}{c}\text { Konsentrasi } \\
(\mathbf{p p m})\end{array}$ & $\begin{array}{c}\text { Absorbansi } \\
\text { blanko }\end{array}$ & $\begin{array}{c}\text { Absorbansi } \\
\text { sampel }\end{array}$ & $\begin{array}{c}\text { Persen inhibisi } \\
(\mathbf{\%})\end{array}$ & $\begin{array}{c}\mathbf{I C}_{\mathbf{5 0}} \\
(\boldsymbol{\mu g} \mathbf{m} \mathbf{m})\end{array}$ \\
\hline Metanol & 20 & 0,837 & 0,725 & 13,381 & 445,255 \\
& 40 & 0,837 & 0,712 & 14,934 & \\
& 60 & 0,837 & 0,693 & 17,204 & \\
& 80 & 0,837 & 0,680 & 18,757 & \\
n-heksan & 100 & 0,837 & 0,669 & 20,071 & 198,065 \\
& 20 & 0,837 & 0,717 & 14,336 & \\
& 40 & 0,837 & 0,688 & 17,801 & \\
Etil & 60 & 0,837 & 0,658 & 21,385 & \\
asetat & 80 & 0,837 & 0,624 & 25,448 & \\
& 100 & 0,837 & 0,579 & 30,824 & \\
& 20 & 0,796 & 0,643 & 19,221 & \\
Air & 60 & 0,796 & 0,623 & 21,733 & \\
& 80 & 0,796 & 0,587 & 26,256 & \\
& 100 & 0,796 & 0,567 & 28,768 & \\
& 20 & 0,796 & 0,533 & 33,040 & \\
& 40 & 0,816 & 0,722 & 11,519 & 2749,07 \\
& 60 & 0,816 & 0,720 & 11,764 & \\
\hline
\end{tabular}

Tabel 7. Pengukuran absorbansi, presentase pengikatan $\mathrm{DPPH}$, dan nilai $\mathrm{IC}_{50}$ dari pembanding kuarsetin

\begin{tabular}{|c|c|c|c|c|c|}
\hline Sampel & $\begin{array}{l}\text { Konsentrasi } \\
\quad(\mathbf{p p m})\end{array}$ & $\begin{array}{c}\text { Absorbansi } \\
\text { blanko }\end{array}$ & $\begin{array}{c}\text { Absorbansi } \\
\text { sampel }\end{array}$ & $\begin{array}{c}\text { Persen } \\
\text { inhibisi } \\
(\%)\end{array}$ & $\underset{(\mu \mathrm{g} / \mathrm{mL})}{\mathrm{IC}_{50}}$ \\
\hline \multirow{5}{*}{ Kuersetin } & 2 & 0,863 & 0,621 & 28,041 & \multirow{5}{*}{8,382} \\
\hline & 4 & 0,863 & 0,551 & 36,152 & \\
\hline & 6 & 0,863 & 0,494 & 42,757 & \\
\hline & 8 & 0,863 & 0,450 & 47,856 & \\
\hline & 10 & 0,863 & 0,384 & 55,504 & \\
\hline
\end{tabular}


Menurut Phongpaichit et al (2007), suatu senyawa dikatakan sebagai antiradikal bebas sangat kuat apabila nilai $\mathrm{IC}_{50}<10 \mu \mathrm{g} / \mathrm{mL}$, kuat apabila nilai $\mathrm{IC}_{50}$ antara $50-100 \mu \mathrm{g} / \mathrm{mL}$, sedang apabila nilai $\mathrm{IC}_{50}$ berkisar antara $100-150 \mu \mathrm{g} / \mathrm{mL}$, lemah apabila nilai $\mathrm{IC}_{50}$ berkisar antara $150-200 \mu \mathrm{g} / \mathrm{mL}$ dan tidak aktif apabila $\mathrm{IC}_{50}$ diatas $250 \mu \mathrm{g} / \mathrm{mL}$.

Semakin kecil nilai $\mathrm{IC}_{50}$, maka semakin aktif sampel tersebut sebagai antioksidan. Pada penelitian ini diperoleh nilai $\mathrm{IC}_{50}$ dari sampel ekstrak metanol, fraksi n-heksan, fraksi etil asetat dan fraksi air kulit buah naga merah (Hylocereus polyrhizus) dengan nilai $\mathrm{IC}_{50}$ untuk ekstrak metanol $\mathrm{IC}_{50} 445,255 \mu \mathrm{g} / \mathrm{mL}$, fraksi n-heksan $\mathrm{IC}_{50} 198,065 \mu \mathrm{g} / \mathrm{mL}$, dan fraksi etil asetat $\mathrm{IC}_{50} 199,527 \mu \mathrm{g} / \mathrm{mL}$. Nilai ini menyatakan bahwa ekstrak metanol, fraksi n-heksan dan fraksi etil kulit buah naga merah (Hylocereus polyrhizus) memiliki aktivitas antioksidan yang kurang aktif, namun tetap memiliki potensi antioksidan karena memiliki nilai $\mathrm{IC}_{50}$ yang berkisar antara 200-1000 $\mu \mathrm{g} / \mathrm{mL}$ (Molyneux, 2004). Untuk fraksi air memiliki nilai $\mathrm{IC}_{50} 2749,078 \mu \mathrm{g} / \mathrm{mL}$ ini menyatakan bahwa fraksi air yang tidak aktif.

Sedangkan kuersetin yang diperoleh sebesar $8,382 \mu \mathrm{g} / \mathrm{mL}$, ini menunjukkan bahwa kuersetin memiliki aktivitas antioksidan yang sangat kuat karena memiliki nilai $\mathrm{IC}_{50}<50 \mu \mathrm{g} / \mathrm{mL}$.

Perhitungan persen inhibisi adalah kemampuan suatu bahan untuk menghambat aktivitas radikal bebas yang berhubungan dengan konsentrasi suatu bahan. Nilai $\mathrm{IC}_{50}$ sendiri merupakan salah satu parameter yang biasa digunakan untuk menginterpretasikan hasil dari pengujian DPPH.

\section{KESIMPULAN}

Dari hasil penelitian yang telah dilakukan dapat disimpulkan bahwa:

1. Isolat fraksi n-heksan kulit buah naga merah (Hylocereus polyrhizus) memiliki aktivitas antioksidan.

2. Isolat fraksi n-heksan kulit buah naga merah (Hylocereus polyrhizus) adalah golongan senyawa flavonoid

3. Uji aktivitas antioksidan kulit buah naga merah (Hylocereus polyrhizus) dengan nilai $\mathrm{IC}_{50}$ untuk ekstrak metanol $\mathrm{IC}_{50} 445,255 \mu \mathrm{g} / \mathrm{mL}$, fraksi nheksan $\mathrm{IC}_{50} 198,065 \mu \mathrm{g} / \mathrm{mL}$, dan fraksi etil asetat $\mathrm{IC}_{50} \quad 199,527 \mu \mathrm{g} / \mathrm{mL}$ memiliki aktivitas antioksidan yang kurang aktif, namun tetap memiliki potensi antioksidan. Untuk fraksi air memiliki nilai $\mathrm{IC}_{50} \quad 2749,078 \mu \mathrm{g} / \mathrm{mL}$ ini menyatakan bahwa fraksi air yang tidak aktif sebagai antioksidan. Sedangkan kuersetin yang diperoleh sebesar $8,382 \mu \mathrm{g} / \mathrm{mL}$ menunjukkan bahwa kuersetin memiliki aktivitas antioksidan yang sangat kuat.

\section{DAFTAR PUSTAKA}

Agoes, Goeswin, 2007, Teknologi Bahan Alam, Penerbit ITB, Bandung.

Ahmad, A, R, A, A, Kosman, R, 2014, 'Standarization of Simplisia and Methanolic Extract of Cemba (Acacia rugata (Lam.) Fawc Rendle) Leaves Endemic Plant From Massenrenpulu Regency of Enrekang', World Journal of Pharmaceutical Sciences, vol.2, no. 12, pp. 1808-1812.

Auterhoff, H, \& Kovar, K.A, 2002, Identifikasi Obat, Edisi V, trans. N.C. Sugiarso, Penerbit ITB, Bandung.

Bendra, A 2012, 'Uji Aktivitas Antioksidan Ekstrak Daun Premna oblongata Miq.', S.Farm Skripsi, Program Studi Ekstensi Farmasi, Universitas Indonesia.

Budilaksono, W., Wahdaningsih, S., Fahrurroji, A., 2014, 'Uji Aktivitas Antioksidan Fraksi Nheksana Kulit Buah Naga Merah (Hylocereus lemarei Britton and Rose) Menggunakan Metode DPPH (1,1-diphenyl2-picrylhydrazil)', Universitas Tanjungpura.

Cahyono, B., 2009, Buku Terlengkap Sukses Bertanam Buah Naga, Pustaka Mina, Jakarta.

Departemen Kesehatan Republik Indonesia, 2000, Parameter Standar Umum Ekstrak Tumbuhan Obat, Departemen Kesehatan Republik Indonesia, Jakarta.

Direktorat Jenderal Pengawas Obat dan Makanan, 2014, Farmakope Indonesia, Edisi V, Departemen Kesehatan Republik Indonesia, Jakarta.

Gunasena, HPM, \& Pushpakumara, DKNG 2006, Dragon Fruit-Hylocereus undatus (Haw.) Britton and Rose Fruit For The Future', Sri Lanka Council For Agricultural Policy, Wijerama Mawatha, Colombo 7, Sri Lanka, p. 114.

Harmita, 2006, Buku Ajar Kromatografi, Departemen Farmasi Fakultas Matematika \& Ilmu Pengetahuan Alam, Universitas Indonesia, Jakarta.

Harmita, 2009, Analisis Fisikokimia: Kromatografi, vol. 2, Penerbit Buku Kedokteran EGC, Jakarta.

Heftmann, E., 2003, Steroids Dalam Kromatografi, Fundamentals and Aplication, Amsterdam.

Hernani, \& Rahardja, 2005, Tanaman Berkhasiat Antioksidan, Jakarta: Penebar Swadaya, pp. 13; 79-80.

Integreds Taxonomi Information System, 2016, Hylocereus polyrhizus \& Hylocereus 
undatus, diakses tanggal 20 november 2016 , (http://www.itis.gov).

Khaira, K, 2010, Menangkal Radikal Bebas dengan Antioksidan, Vol. 2. No. 2 pp. 183-186.

Kosasih, EN, Setiabudhi, T, Heryanto, H 2004, Peranan Antioksidan Pada Lanjut Usia, Pusat Kajian Nasional Masalah Lanjut Usia, Jakarta.

Kristanto, D, 2008, Buah Naga Pembudidayaan di Pot dan di Kebun, Penebar Swadaya, Bogor, pp.14-16.

Leba, M, A, 2017, Buku Ajar : Ekstraksi dan Real Kromatografi, Deepublish : Yogyakarta.

Mitasari, A., 2012, 'Uji Aktivitas Ekstra Kloroform Kulit Buah Naga Merah (Hylocereus polyrhizus Britton \& Rose) Menggunakan Metode DPPH (1,1-Defenil-2-Pikril Hidrazil)', Skripsi, Program Studi Farmasi, Universitas Tanjungpura, pp. 37-38.

Molyneux, P 2004, 'The Use Of The Stable Free Radical Diphenyl Picrylhydrazyl (DPPH) For Estimating Antioxidant Activity' Songklanakarin Journal Science Technology, vol 26, no.2, pp. 211-219.

Munson, 2010, 'Plant Resources of South East Asia, Edible Fruits and Nuts', Prosea Foundation, Bogor.

Nasution, 2010, Pharmacochemical Investigation on Raw Materialsof Passiflora Edulis Forma Flavicarpa,: Planta Med.

Nisa, GK, Nugroho, WA, \& Hendrawan, Y 2014. 'Ekstraksi Daun Sirih Merah (Piper crocatum) dengan metode microwave assisted extraction (MAE)', Jurnal Biopress Komoditas Tropis, vol. 2, no. 1, pp. 72-78.

Nuari, S., Anam, S., \& Khumaidi, A., 2017, 'Isolasi dan Identifikasi Senyawa Flavonoid Ekstrak Etanol Buah Naga Merah (Hylocereus polyrhizus (F.A.C. Weber) Briton \& Rose)', Jurnal Farmasi Galenika: Galenika Jurnal of Pharmacy, 3(2), pp. 118-125.

Nurliyana, R., Zahir, I. S., Suleiman, K. M., Aisyah, M. R., \& Rahim, K. K., 2010, 'Antioxidant Study of Pulps and Peels of Dragon Fruits: a comparative study', International Food Research Journal, pp. 17: 367-365.

Oxtoby, D, W, Gilis, H, P, \& Campion, A, 2011, Principles of modern chemistry, $7^{\text {th }}$ edn, Brooks Cole Cengage Learning, USA.

Pranata, R., Wahdaningsih, S., \& Fahrurroji, A., 2014, 'Uji Aktivitas Antioksidan Fraksi Kloroform Buah Naga Merah (Hylocereus lemairei Britton dan Rose) Menggunakan Metode DPPH (1,1-Difenil-2Pikrilhidrazil)', Jurnal Mahasiswa Farmasi Fakultas Kedokteran UNTAN.
Rohman, A, 2009, Kromatografi Untuk Analisa Obat, Graha Ilmu, Yogyakarta.

Rusli, R 2009, 'Penetapan Kadar Boraks Pada Mie Basah Yang Beredar Dipasar Ciputat Dengan Metode Spektrofotometer UV-VIS Menggunakan Pereaksi Kurkumin', S.Ked Skripsi, Fakultas Kedokteran dan Ilmu Kesehatan, Universitas Islam Negeri (UIN) Syarif Hidayatullah.

Saifuddin, A, 2014, Senyawa Alam Metabolit Sekunder, Teori, Konsep dan Teknik Pemurnian, Yogyakarta.

Sayuti, K, Yenrina, R, 2015, Antioksidan Alami dan Sintetik. Andalas University Press, Padang, pp. 7, 32-38 \& 75-77.

Sudjadi., 2007, Kimia Farmasi Analisis, Pustaka Pelajar, Yogyakarta. Thomas A.N.S., 1992. Tanaman obat tradisional 2, Kanisius: Yogyakarta.

Tobo, F., 2001, Buku Pegangan Laboratorium Fitokimia I, Universitas Hasanuddin, Makassar.

Warisno, Dahana, K 2010, Buku Pintar Bertanam Buah Naga, Gramedia Pustaka Utama, Jakarta, p. 11.

Widyastuti, Fratama, I. Rizqi, \& Seprialdi, A, 2015, 'Pengujian Aktivitas Antioksidan dan Tabir Surya EKstrak Etanol Kulit Buah Naga Super Merah (Hylocereus costaricensis (F.A.C. Weber) Britton \& Rose)', Vol. 5, No. 2, pp. 70-71.

Winarsih, 2007, Mengenal dan Membudidayakan Buah Naga, Semarang.

Winarsih, H., 2007, Antioksidan Alami dan Radikal Bebas, Yogyakarta: Kanisius, pp:13; 79-80.

Wulandari, Lestyo, 2011, Kromatografi Lapis Tipis, Taman Kampus Presindo, Jember.

Wu, L. C., Hsu, H. W., Chen, Y., Chiu, C.C., and Ho, Y. I., 2006, 'Antioxidant and Antiproliferative Activities of Red Pitaya', Food Chemistry Volume, 95: 319-327. 